\title{
RURAL AREA RESOURCE MANAGEMENT: THE CASE OF HUNGARY - CROATIA IPA CROSS-BRODER COOPERATION
}

\author{
Sanela Ravlić ${ }^{1}$, Jerko Glavaš² \& Damir Šebo ${ }^{3}$
}

\author{
UDC / UDK: 005.96:711.3:339.92(497.5:439)(4-67EU) \\ JEL classification / JEL klasifikacija: P25, O15 \\ DOI: https://doi.org/10.22598/pi-be/2020.14.1.159 \\ Scientific review / Pregledni znanstveni rad \\ Received / Primljeno: March 10, 2020 / 10. ožujka 2020. \\ Accepted for publishing / Prihvaćeno za tisak: May 15, 2020 / 15. svibnja \\ 2020.
}

\section{Summary}

Resource management of a particular area is nowadays one of the greatest challenges, especially when it comes to more sensitive areas, such as rural areas. Human resources, alongside mostly limited natural resources, represent an opportunity for rural areas, especially due to the beginning of utilization of considerable EU preaccession funds. This paper presents one part of the primary research results on the views of project implementors and end-users about the impact of the achieved results of IPA CBC Hungary-Croatia 2007-2013 on human resources of the implementing institutions and local communities of the observed, mostly rural area. The conclusion of this research, that was conducted in 2018, is that the funds invested in an observed area had a dual role. First of all, implementing organizations would not have this amount of work and number of employees, nor would they establish partnerships with organizations from another country, carry out activities or develop the skills, knowledge and capabilities of their human resources. Also, the implementation of their project has increased the number of contacts and collaborations with organizations at a local level, which is a significant resource for the future. On the other hand, the funds have enabled users, residents of local communities along the border, to acquire new skills, increase

\footnotetext{
${ }^{1}$ Sanela Ravlić, PhD, Senior adviser for project implementation, Croatian Emplyoment Service Regional Office Osijek, Department for project implementation, Osijek, Croatia, E-mail: ravlic.sanela@gmail.com

${ }^{2}$ Jerko Glavaš, Ph.D., Associate Professor, Josip Juraj Strossmayer University of Osijek, Faculty of Economics in Osijek, Department of Management, Organisation and Entrapreneurship, Osijek, Croatia, E-mail: jerko.glavas@efos.hr

${ }^{3}$ Damir Šebo, PhD., Assistant Professor, Josip Juraj Strossmayer University of Osijek, Academy of Arts and Culture, Department of Culture, Media and Management, Osijek, Croatia, E-mail: dsebo@aukos.hr
} 
knowledge and abilities they can use for further development, to understand the importance of lifelong learning and the increase of active involvement in a local community. In conclusion, the project implementation and the investment in rural areas is an investment in the future due to the diversity of processes they can activate.

Key words: rural area resource management, primary research, Cross-Border Cooperation, Regional Development, European Union.

\section{INTRODUCTION}

The resource management of a region that borders with another country is extremely important since ,37,50\% of the EU population live in the border areas that are defined by 38 international borders"(Flash Eurobarometer 422, 2015.). Regional policy is one of the major pillars of the entire EU public policy, focused on the redistribution of resources of the member states with the intent to boost economic growth and sustainable development of the underdeveloped areas (Đulabic and Manojlović, 2011.). Regional policy is widely discussed across Europe among researches in past decades, in terms of pros and cons (Hooghe and Keating, 1994., Begg et al., 1995., Dignan, 1995., Armstrong, 1996., Bache, 1998., Martin, 1999., Basile et al., 2001., Glen, 2002., Cappelen et al., 2003., Barry, 2003.). It should be highlighted that regional policy is based on financial solidarity, which should ensure that all regions and its citizens can fully benefit from the single market, as well as the economic and monetary union. Regions are very often less populated but considered well "rounded" spaces within which economic entities can optimally solve many common issues (Ležaić et al., 2010., Čavrak, 2011.,) that is, to ensure that underdeveloped regions in the restructuring process are able to respond to intense competitive pressures in the single market (Kersan-Škabić, 2005.). It is also crucial to take into account the development challenges, specificities, threats and the opportunities of each region, especially in the case of some Croatian counties (Babić, 2004.). Situation is even more complex in the regions where there is one urban center or several smaller ones with a high percentage of rural area surrounding it. The impacts on territorial cohesion among bordering countries, as well as impacts on EU level, need to be observed from a wider regional perspective to understand the benefits and possible threats (Sumpor and Kuzmić, 2011.). In addition, the rural areas of the border regions are facing even more complex difficulties that need to be adapted and systematically monitored. Resources and their management, especially in rural areas, will prove to be crucial/great importance, since significant differences in regional (county) development, diversity of economic opportunities, specificity of problems faced by individual counties require specific solutions and strengthening of the "bottom-up" approach. A balanced regional development is an issue on the global level, but also regional differences are recognized as a certain threat to the level of national economies, European and world level (Barković Bojanić et al., 2013.). Regional development is not just about investing in infrastructure and doing identical interventions in every space, rural or urban, within one country or across border. It requires tailored activities to improve the 
entrepreneurial climate, entrepreneurship development, education, the labour market, or people and their knowledge. It is necessary to actively look for solutions at all levels, and systematically monitor them, especially when it comes to human resources, since people are becoming increasingly mobile. The problem is that individuals are the ones who must recognize the value that enables them to improve their material position and quality of life (Sundać and Fatur Krmpotić, 2009.)

Unfortunately, "Human capital is rarely discussed and very poorly managed in Croatia" (Šinko, 2015). Therefore, changes are needed at all levels in order to provide the same opportunities in local communities and rural areas as, for example, urban centers in a region already have. What certainly should be in a focus as a potential for the development of the observed area is the aspiration to create the society that we describe in our strategic documents. The dynamics, adaptability and competitiveness of more knowledge-based ('learning') societies are linked to the degree of citizens' involvement, especially in the various forms of lifelong learning and the quality of the education process (Sučić et al, 2011., Sudarić, 2012.). In addition to being desirable that the individuals constantly learn, this is also true of organizations. It is important that they also constantly learn and support the learning environment - within the economy, but also within public, state and local government (Strategija obrazovanja, znanosti i tehnologije, 2014.), as well as at the local community level. In the context of project implementation, all levels, beginning from Level 1 and Level 2 Contracting Authorities to institutions at a regional and local level, should have people who are ready to learn and acquire new skills and knowledge. Project implementation requires transversal skills (UNESCO-IBE, 2013; UNESCO, 2013,) and continuous acquisition of new knowledge and skills in order to keep up with changes in a challenging life cycle of projects funded from pre-accession funds, as well as the future ones from structural and cohesion funds. The aim of this paper is to present the results of a survey on the views of project implementers within IPA CBC HU - HR 2007 - 2013 which were conducted in the rural areas along the Hungarian and Croatian border with only large urban centres in the region, Pecs and Osijek and several smaller centres.

\section{MATERIALS AND METHODS}

The primary research, which results will be partially presented in this paper, was conducted from 1st of April to 31st of May 2018. The method used for this survey was a questionnaire that was sent to organisations that implemented projects within the IPA Cross-Border Cooperation Hungary-Republic of Croatia, Financial Perspective 2007-2013. (IPA Prekogranični program Mađarska - Hrvatska, Programski dokument za programsko razdoblje 2007.-2013., 2013.).

The area is geographically located along the southwestern and southern border of Hungary and the northern and northeastern border of the Republic of Croatia. On the side of the Republic of Croatia, the research was conducted in the bordering counties of Međimurje, Koprivnica-Križevci, Virovitica-Podravina and Osijek-Baranja, but also in the associated counties (Varaždin, Bjelovar-Bilogora, Požega-Slavonia and Vukovar- 
Srijem) which can be nominated for up to $20,00 \%$ of the allocated EU funding available under the Programme. The areas that participated in the research from the Hungarian side are Zala County, which is a part of the Western Transdanubia region, the Somogy and Baranya counties, which are a part of the South Danube region. The survey consisted of 38 questions (41 variables) and was conducted by using the Type Form online form. The corrective method was planned in the form of an interview method, but not implemented since no clarification of given answers to the survey were needed from the respondents. The collected data were processed by appropriate statistical methods. Data analysis was done using SPSS v23. Map processing and presentation was done in QGIS 3.4. The respondents were implementers of the projects implemented during the 7-year period from 2007 to 2013 , according to the $n+3$ rule. Of the potential 170, 102 respondents participated, representing 358 institutions out of a total of 581 institutions that took part in the projects under the 3 conducted Calls. The funding within IPA CBC HU - CRO 2007. - 2013. is intended for two priorities - (1) Sustainable environment and tourism and (2) Development of economic cooperation and common human capacities (Prioriteti programa prekogranične suradnje Mađarska Hrvatska, 2013.).

The involved institutions included public sector institutions, educational and research institutions, trust funds, various chambers, public employment services, regional and local authorities (counties, cities and municipalities), regional development agencies, business incubators, entrepreneurial centres, R\&D centres, associations, NGOs, employers' associations, professional associations, trade unions, agricultural associations and cooperatives. In addition to statistical analysis, the data are also presented in a geographical map of the cross-border area. The human resource in the cross-border area will be in the paper partially observed at the level of institutions, implementers of projects and at the level of individuals, beneficiaries in the project.

\section{RESULTS AND DISCUSSION}

Out of the entire scope of conducted research, two sections will be shown in this paper. The first section within Table 2. shows the attitude of institutions that implemented projects in cross-border area, thus their human resources - project managers, project assistants, project team members that implemented projects on local levels in cross-border rural and urban areas of two countries. Table 1. presents the distribution of types of organisations. Further, Figure 1 displays the dispersion of implemented projects in the cross-border urban and rural areas in south-western and southern part of Hungary and the northern and north-eastern region of the Republic of Croatia.

The second part, Graph 1. and Table 3., is focused mostly on beneficiaries, target group members from local communities in mostly rural areas, who took part in the activities that were implemented in the CBC area. Their attitude towards the implementers within the 7 years of the program from both countries, can provide an important insight into created effects, both in a positive and negative direction, but also 
possible future correction methods. In this way negative impacts could be detected timely and included into future measures in order to correct the issues. Positive created impacts should be tracked in order to detect their multiplication strength in the local communities.

Figure 1. Graphic display of the locations of the implemented projects in the crossborder area

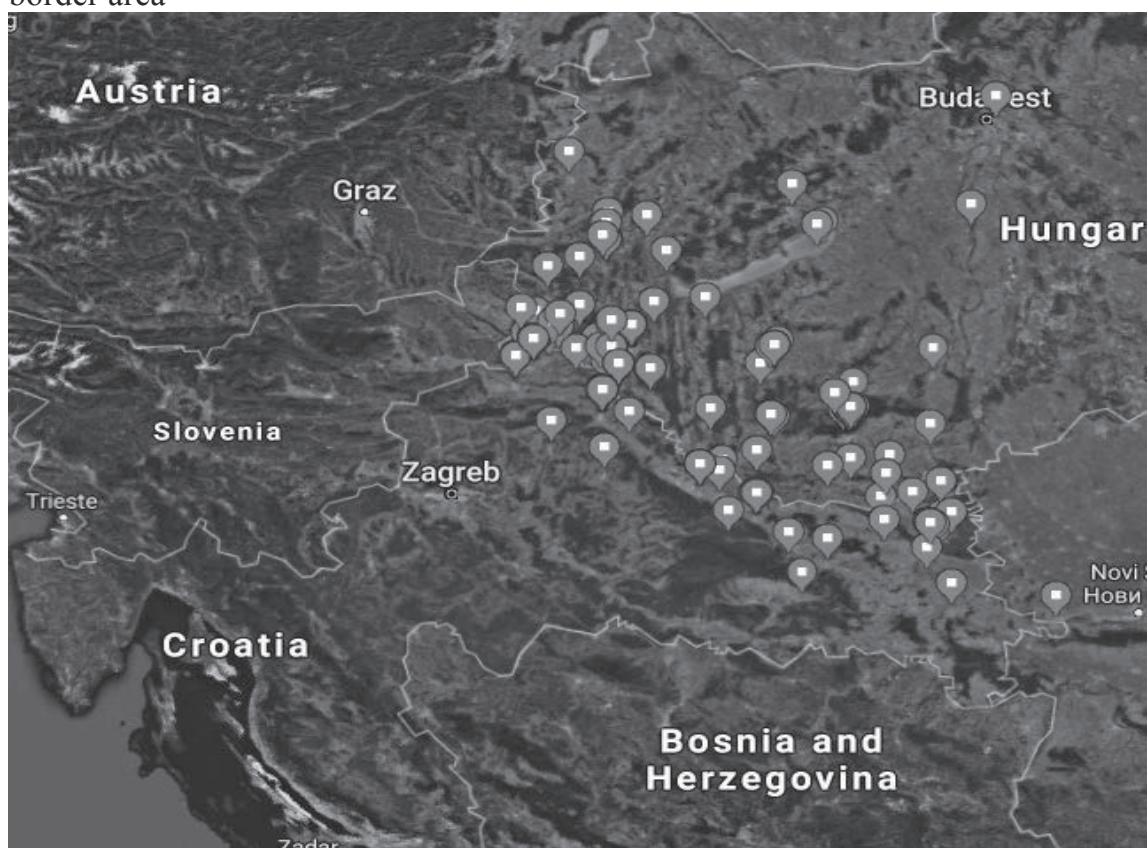

Source: Authors

Both sides of the eligible area of the Program can be characterized as rural areas with the only large urban centers in the region "Pecs (162 498 inhabitants) and Osijek (114 616 inhabitants). Other urban centers that have more local significance are Kaposvár (67 662), Zalaegerszeg (60 061), Nagykanizsa (51 694), Komló (27 387) on the Hungarian side and Koprivnica (25 776), Čakovec (15 885), Virovitica 15 683), Varaždin (49 075) and Bjelovar (41 869) on the Croatian side" (IPA Prekogranični program Mađarska - Hrvatska, Programski dokument za programsko razdoblje 20072013, 2013.).

Table 1. Respondents by type of the organisation

\begin{tabular}{|l|l|l|l|l|}
\hline Type of organisation & Frequency & Percent & $\begin{array}{l}\text { Valid } \\
\text { Percent }\end{array}$ & $\begin{array}{l}\text { Cumulative } \\
\text { Percent }\end{array}$ \\
\hline Institutions & 42 & 41,20 & 41,20 & 41,20 \\
\hline Regional and local authorities & 24 & 23,50 & 23,50 & 64,70 \\
\hline
\end{tabular}


POSLOVNA IZVRSNOST ZAGREB, GOD. XIV (2020) BR. 1 RavlićS., Glavašs., Šebo D.: Rural area resource management: The case og Hungary - Croatia IPA...

\begin{tabular}{|l|l|l|l|l|}
\hline Entrepreneurial support institutions & 22 & 21,60 & 21,60 & 86,30 \\
\hline Non-governmental organisations & 9 & 8,80 & 8,80 & 95,10 \\
\hline $\begin{array}{l}\text { National, regional or local government } \\
\text { owned companies }\end{array}$ & 5 & 4,90 & 4,90 & 100,00 \\
\hline Total & 102 & 100,00 & 100,00 & \\
\hline
\end{tabular}

Source: Authors

As already mentioned, out of the potential 170 respondents from two countries, Hungary and Croatia, 102 respondents took part in the survey. The institutions, i.e. public sector, educational and research institutions from two countries were represented by $41,20 \%$. Further, from the total number of the collected answers within our primary research there was $23,50 \%$ respondents from regional and local authorities (counties, cities, municipalities) from across border and somewhat smaller number, $21,60 \%$, from entrepreneurial support institutions (county development agencies, local development agencies; entrepreneurial/business incubators, entrepreneurial centers, R\&D centers and other business sector support organizations). Also, there was $8,80 \%$ answers from nongovernmental organizations, i.e. civil associations, professional associations (agricultural associations, employers' associations) and trade unions. The lowest number of responses to our survey came from the companies owned by national, regional and local government, only 4,90\%. Associated frequencies are presented in the Table 1 .

Table 2. Statements on implementation of projects in the border regions

\begin{tabular}{|l|c|c|c|c|c|}
\hline Statement & $(1)$ & $(2)$ & $(3)$ & (4) & (5) \\
\hline $\begin{array}{l}\text { Our organization would certainly have this volume } \\
\text { of work and number of employees, regardless of the } \\
\text { implementation of EU projects. }\end{array}$ & 0,60 & 3,70 & 8,40 & 21,60 & 15,70 \\
\hline $\begin{array}{l}\text { Our organization would certainly establish } \\
\text { partnerships with organizations from another } \\
\text { country, partners in the project and carry out the } \\
\text { activities of this project in this volume and without } \\
\text { EU funding or co-financing. }\end{array}$ & 50,00 & 23,53 & 15,69 & 7,84 & 2,94 \\
\hline $\begin{array}{l}\text { Partner organizations have greatly contributed to } \\
\text { development of the skills, knowledge and } \\
\text { capabilities of our organization }\end{array}$ & 2,90 & 4,90 & 19,60 & 41,20 & 31,40 \\
\hline $\begin{array}{l}\text { By transferring knowledge, skills and experience, } \\
\text { we have improved our own business as well as our } \\
\text { partners and associates business in the project. }\end{array}$ & 1,00 & 2,90 & 15,70 & 48,00 & 32,40 \\
\hline $\begin{array}{l}\text { The implementation of this project has increased the } \\
\text { number of contacts and collaborations with } \\
\text { organizations at the local level }\end{array}$ & 0,00 & 4,90 & 6,90 & 47,10 & 41,10 \\
\hline
\end{tabular}

Source: Authors

The answers are presented as a percentage from total of 102 received responses for every statement. They range from a rating of 1 representing the statement "I strongly 
disagree", a rating of 2 "I disagree", a rating of 3 representing "neither agreeing nor disagreeing", a rating of 4 "I agree" and a rating of 5 indicating the statement "I strongly agree". The first statement was confirmed by $37,30 \%$ of the respondents who chose the answer "I strongly agree" and "I agree", which confirms that a really large number of institutions are dependent on financial resources from EU funding without which they would not have current staff or could not plan the project activities that were implemented. In the case of the second statement, we find a high response rate $(50,00 \%)$ in the case of "I strongly disagree" answer to which we can add $23,53 \%$ for "I disagree" answer and conclude that partner organizations on both sides of the border would not establish mutual contact and implement the planned activities without EU support through IPA CBC HU - HR 2007-2013. Regarding the third statement, whether the partner organizations helped to develop organization's skills, knowledge and capabilities, out of the total number of respondents, only 2,90\% selected the statement "I strongly disagree" and 4,90\% selected statement "I disagree". We can conclude with great certainty that partner organizations have mutually influenced the skills development, knowledge and capabilities of their employees and business processes. In case of the last statement, the respondents express a really high degree of accordance with the statement that the implementation of this project has increased the number of contacts and cooperation with organizations at the local level. $47,10 \%$ of respondents opted for the answer "I agree" and $41,10 \%$ of respondents selected the answer "I strongly agree". The obtained data show that respondents highly value the role of the projects implemented in the local communities in mostly rural areas of cross-border cooperation of Hungary and Croatia.

Graph 1. Implementation of sustainability activities of IPA CBC HU - HR projects

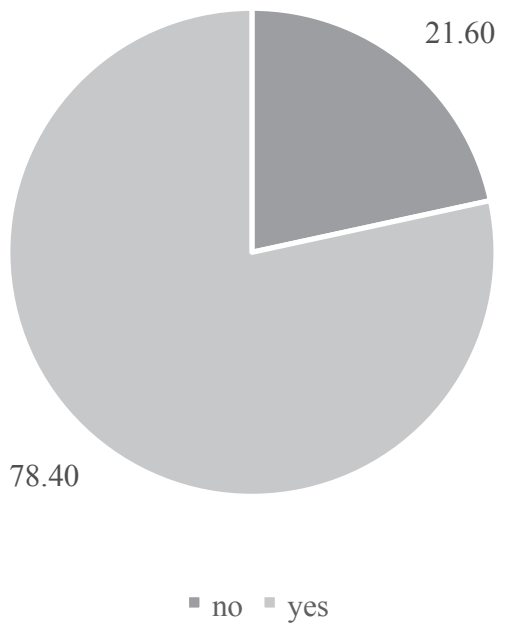

Source: Authors 
The Graph 1. shows the analysis of the collected answers to the question on the implementation of the sustainability activities, which mostly includes project beneficiaries who participated in the project activities under IPA CBC HU - CRO. Some of the projects were completed over 5 years ago. The percentage of positive answers to the question significantly exceeds $21,60 \%$ of organizations that no longer carry out sustainability activities of project results in the area that projects took place. There are $78,40 \%$ of organizations continue to carry out activities in their local communities, and more importantly with local community members, participants in the initial part of the project. Sustainability of project results in local, mostly rural, crossborder communities is a very important segment of project implementation since it means that project results still contribute to the local, mostly rural spaces. Depending on the type of activities undertaken during the project, the sustainability period can play a key role since effects can develop further, reach their full potential and keep influencing the life of the local community in a rural area. If we add to this response the previous ones, we can conclude that the dependency of project implementation and EU funds in a cross-border area, which is largely a rural area, is high, but also that the funds have continued their lives through the continuation of activities in local communities which creates create added value in these communities in the long run.

Table 3. Statements on attitudes of project beneficiaries from local communities in the border regions

\begin{tabular}{|l|c|c|c|c|c|}
\hline Statement & $(1)$ & $(2)$ & $(3)$ & $(4)$ & $(5)$ \\
\hline $\begin{array}{l}\text { Beneficiaries have increased their } \\
\text { knowledge, skills and / or abilities. }\end{array}$ & 0 & 0 & 12,70 & 49,00 & 38,20 \\
\hline $\begin{array}{l}\text { They used the acquired knowledge } \\
\text { and skills after the implementation of } \\
\text { the project in order to develop future } \\
\text { activities. }\end{array}$ & 0 & 2,00 & 21,60 & 43,10 & 33,30 \\
\hline $\begin{array}{l}\text { Beneficiaries recognize the } \\
\text { importance of continuing to acquire } \\
\text { additional knowledge, skills and/or } \\
\text { abilities and engage in further } \\
\text { training. }\end{array}$ & 0 & 3,90 & 24,50 & 40,20 & 31,40 \\
\hline $\begin{array}{l}\text { Beneficiaries are more involved in } \\
\text { the functioning and operation of their } \\
\text { local community. }\end{array}$ & 1,00 & 3,90 & 35,30 & 37,30 & 22,50 \\
\hline
\end{tabular}

Source: Authors

The answers again range from a rating of 1 representing the statement "I strongly disagree", a rating of 2 "I disagree", a rating of 3 representing "neither agreeing nor disagreeing", a rating of 4 "I agree" and a rating of 5 indicating the statement "I strongly agree". Analysis of the collected data on the attitude of the implementers regarding the improvement of the knowledge, skills and abilities of the target group members point out/indicates quite high values for the statements "I agree" 
and "I strongly agree", which means that the improvement of knowledge, skills and ability has multiple effects on many levels. Given the rapid changes that are occurring in the labour market caused by development in almost all sectors, the importance of continuous learning cannot be sufficiently emphasized. Although formal education is necessary and inevitable for each individual, it is not enough in its content for the entire working life of a person. Continuous education which can help a person to upgrade and/or acquire specific knowledge, skills and abilities from a segment that is necessary for its profession, especially in rural areas where opportunity are scarce, is highly important. The projects included employees, those who wish to improve their knowledge, skills and abilities, as well as those who are currently unemployed or inactive in the labour market. Regardless of the group, each of the participants, as stated by the project implementers, has improved their knowledge, skills and abilities, which is and will be important for a person's future life, especially in rural areas. The high value for statements "I agree" and "I strongly agree" in the second statement confirms that the participants value the activities they were able to attend during the project, which will certainly have an impact on the future growth and development of the area and its human resources. The development of a person at any stage of his or her life will provide both immediate and long-term effects. Precisely those long-term effects that cannot be fully captured and explained are very important for understanding the impact of the invested funds. However, a positive assessment and satisfaction of users over a long period of time, as is the case here, confirms that education and development mentioned above enabled individuals to make the changes that would not occur if the projects had not been implemented. The abovementioned has brought change to beneficiaries on multiple levels and created opportunities for that specific person but also to the people in their immediate vicinity. Furthermore, according to the analysis of the obtained data, the project promoters confirm that the beneficiaries, members of the target group of the project, after carrying out the project activities, recognize the importance of continuous acquisition of additional knowledge, skills and abilities and have engaged in further training. Participation in further development and learning confirms satisfaction with previous participation in project activities that have contributed to their high motivation for future development. In addition to beneficiaries,' satisfaction, the quality of a project preparation and all planned activities by institutions in a partnership that is in line with community needs in the cross-border area, which has certainly contributed greatly to customer satisfaction, is confirmed. Considering that they were planned and prepared by the project promoters, it can be concluded that human resources within institutions have sufficient knowledge about the needs in the communities and the skills to translate them into project-specific terminology.

The development of each individual, member of the local community in the last stage will be manifested in his involvement in his local community according to his preferences - to engage in various existing types of association, to create some new value for the local community or to start an enterprise that the individual desires and possess sufficient skills, knowledge and abilities necessary for its success. The last statement "Beneficiaries are more involved in the functioning and operation of their 
local community" has somewhat lower value than other statements, but still the overall value and the percentage of their agreement with the statement expresses high values. The purpose of this question was to try to quantify the potential for increased action in the local community, which is certainly a sign of a person's confidence in the community and the further possible construction of the social capital of that community. This confirms the importance of improving the knowledge, skills and capabilities of the residents of the cross-border area especially in more deprived, rural areas. The obtained results are certainly in favour of a positive change in local communities along the border, so the step toward desired situations both in rural and urban areas is visible.

\section{CONCLUSION}

The EU funds that were invested in the development of human resources in the observed area have a dual role. First of all, funding influenced the acquisition of new knowledge and skills necessary for a successful projects implementation by employees of these institutions. This is confirmed with the research results which show that organizations would not certainly have this volume of work and number of employees without EU funding nor would they establish partnerships with organizations from another country, carried out the activities or developed the skills, knowledge and capabilities of their human resources. Also, the implementation of their project has increased the number of contacts and collaborations with organizations at the local level, which is a great resource for future.

To conclude, it is possible to see the interconnectedness and necessity of action at all levels, that is, the active participation of local and regional stakeholders if talking about cross-border cooperation. Project implementation or investment in rural areas is an investment in the future due to the diversity of processes that can activate them. Second of all, funds allowed target group members, residents of local communities along the border to gain new skills through participation in EU projects and to realize their potentials in the rural areas where they currently live. The invested funds within seven years has increased their knowledge, as well as the skills and abilities that they can use for further development, their better understanding of the importance of lifelong learning and that their more active involvement in their local communities.

\section{REFERENCES}

1. Armstrong, H. W. (1996). European Union regional policy: sleepwalking to a crisis. International Regional Science Review, 19(3), 193-209. http://dx.doi.org/10.1177/016001769601900301

2. Babić, D. (2004). Materijalni i sociopsihološki čimbenici (re)konstrukcije lokalnih zajednica nakon ratnih sukoba (prostori posebne državne skrbi). Revija za socijalnu politiku, 11(3), 363-382., URL: http://www.rsp.hr/ojs2/index.php/rsp/article/viewFile/36/48 [10.11.2019.] 
3. Bache, I. (1998). Politics of European Union Regional Policy: Multi-Level Governance or Flexible Gatekeeping? (Vol. 3). A\&C Black.

4. Barković Bojanić, I., Kiss, T., Marošević, K. (2013). Regional development in the Republic of Croatia and Hungary: current situation and future perspectives. Pravo-regije-razvoj. Grafika d.o.o.

5. Barry, F. (2003). European Union Regional Aid and Irish Economic development. Funck, B. and L. Pizzati (eds.), 135-152.

6. Basile, R., De Nardis, S., Girardi, A. (2001). Regional inequalities and cohesion policies in the European Union. http://dx.doi.org/10.2139/ssrn.936319

7. Begg, I., Gudgin, G., Morris, D. (1995). The assessment: Regional policy in the European Union. Oxford Review of Economic Policy, 11(2), 1-17. http://dx.doi.org/10.1093/oxrep/11.2.1

8. Cappelen, A., Castellacci, F., Fagerberg, J., Verspagen, B. (2003). The impact of EU regional support on growth and convergence in the European Union.

JCMS: Journal of Common Market Studies, 41(4), 621-644. http://dx.doi.org/10.1111/1468-5965.00438

9. Čavrak, V. (2011): Regionalna politika i regionalne nejednakosti u Hrvatskoj, U: Gospodarstvo Hrvatske, Čavrak, V., Politička kultura. Zagreb, 321-348.

10. Dignan, T. (1995). Regional disparities and regional policy in the European Union. Oxford Review of Economic Policy, 11(2), 64-95. http://dx.doi.org/10.1093/oxrep/11.2.64

11. Đulabić, V., Manojlović, R. (2011). Administrative aspects of Regional and cohesion Policy in Croatia: In Search of a Better coordination of Parallel Processes. Croatian and Comparative Public Administration. 11.4, 1041-1074.

12. Flash Eurobarometer 422: Cross-border cooperation in the EU, URL: http://data.europa.eu/euodp/en/data/dataset/S1565_422_ENG, [3.10.2019.]

13. Glen, C. M. (2002). Regional convergence and regional policy in the European Union. Journal of Political Science, 30(1), 2.

14. Hooghe, L., Keating, M. (1994). The politics of European Union regional policy. Journal of European Public Policy, 1(3), 367-393. http://dx.doi.org/10.1080/13501769408406965

15. IPA Prekogranični program Mađarska - Hrvatska, Programski dokument za programsko razdoblje 2007.-2013., 2013. URL: http://www.hu-hripa.com/en/downloads/programming-document, [5.11.2019.]

16. Kersan-Škabić, I. (2005). Koliko je Hrvatska spremna iskoristiti sredstva regionalne politike Europske unije? Primjer Istre., URL: http://www.ijf.hr/Eu3/kersan-skabic.pdf [16.10.2019.]

17. Ležaić, K., Marhold, H., Leunig, R., Jopp, M. (2010). Cross border cooperation as an instrument of EU regional policy: Case study: Croatia. Institut européen des hautes etudes internationals, Nice.

18. Martin R. (1999) The Regional Policy of the European Union. In: The Regional Dimension in European Public Policy. Palgrave Macmillan, London https://doi.org/10.1057/9780333982594_5 
19. Prioriteti programa prekogranične suradnje Mađarska - Hrvatska, 2013. URL: http://www.hu-hr-ipa.com/hr/prioriteti, [20.10.2019.]

20. Šinko, A. (2015) Uloga ljudskih resursa u ekonomskom rastu Republike Hrvatske. Diplomski rad, Sveučilište sjever, Sveučilišni centar varaždin. Studij Poslovna ekonomija., URL: https://repozitorij.unin.hr/islandora/object/unin\%3A136/datastream/PDF/view [10.11.2019.]

21. Sučić, G., Požega, Ž., Crnković, B. (2011). Education in the function of acquiring applicable knowledge as a response to the global crisis. Correction of the journal ITRO 2011. URL: http://tfzr.rs/casopisitro/files/Casopis\%20ITRO2012.pdf\#page=117 [21.10.2019.]

22. Sudarić, Ž. (2012). Obrazovanje + cjeloživotno učenje za poduzetništvo $=$ zapošljivost. Učenje za poduzetništvo, 2(1), str. 71-75., URL: http://hrcak.srce.hr/130177 (30.10.2019.)

23. Sumpor, M., Kuzmić, M., (2011). Sustainable Development Aspects in CrossBorder Cooperation Programmes: The Case of Croatia and Montenegro. URL: https://bib.irb.hr/datoteka/563221.479.pdf [10.10.2019.]

24. Sundać, D., Fatur Krmpotić, I. (2009). Vrijednost ljudskoga kapitala u Hrvatskoj-usporedba s odabranim europskim zemljama. Ekonomski pregled, 60(7-8), 315-331.

25. UNESCO (2013). Asia-Pacific Education Policy Brief, Skills for Holistic Human Development. Vol 2. URL: http://www.unescobkk.org/fileadmin/user upload/epr/PDF/Policy_Brief Vol2 -28 Nov.pdf [9.11.2019.]

26. UNESCO International Bureau of Education (2013) Glossary of Curriculum Terminology., URL: http://www.ibe.unesco.org/fileadmin/user_upload/Publications/IBE_GlossaryC urriculumTerminology2013 eng.pdf [10.11.2019.]

27. Vlada Republike Hrvatske. (2014). Strategija obrazovanja, znanosti i tehnologije., URL: https://vlada.gov.hr/UserDocsImages//2016/Glavno\%20tajni\%C5\%A1tvo/Mat erijali\%20za\%20istaknuto/2014/Strategija \%20obrazovanja $\% 20$ znanosti $\% 20 \mathrm{i} \%$ 20tehnologije//Cjelovit\%20sadr\%C5\%BEaj\%20Strategije\%20obrazovanja, $\% 2$ 0znanosti\%20i\%20tehnologije.pdf [10.11.2019.] 
POSLOVNA IZVRSNOST ZAGREB, GOD. XIV (2020) BR. 1 RavlićS., GlavaŠJ., Šebo D.: Rural area resource management: The case og Hungary - Croatia IPA...

\title{
UPRAVLJANJE RESURSIMA RURALNIH PROSTORA: PRIMJER IPA PREKOGRANIČNE SURADNJE IZMEĐU MAĐARSKE I HRVATSKE
}

\author{
Sanela Ravlić, Jerko Glavaš \& Damir Šebo
}

\begin{abstract}
Sažetak
Upravljanje resursima nekog prostora predstavlja jedno od najvecih izazova današnjice, poglavito u slučaju osjetljivijih područja poput ruralnih prostora. Ljudski resurs, uz prirodne resurse koji su mahom ograničeni, predstavlja mogućnost za ruralni prostor pogotovo s početkom iskorištavanja znatnih sredstava pretpristupnih fondova EU. U radu je prikazan dio rezultata primarnog istraživanja stavova provoditelja projekata $i$ krajnjih korisnika o utjecaju ostvarenih rezultata programa IPA CBC Mađarska-Hrvatska 2007. - 2013. na ljudski resurs institucija provoditelja i lokalnih zajednica promatranoga prostora koji je većinom ruralnoga karaktera. Zaključak istraživanja jest kako su uložena sredstva na promatranom području imala dvojaku ulogu. U slučaju organizacija provoditelja projekata, one ne bi imale ovaj obujam posla i broj zaposlenih niti bi uspostavile partnerstva s organizacijama iz druge države, provodile aktivnosti ili razvijale vještine, znanje i sposobnosti svojih ljudskih resursa. Također, provedba njihovog projekta povećala je broj kontakata i suradnji s organizacijama na lokalnoj razini što je značajan resurs za budućnost. Nadalje, sredstva su omogućila korisnicima, stanovnicima lokalnih zajednica duž granice, stjecanje novih vještina, povećanje znanja i sposobnosti koje mogu koristiti za daljnji razvoj, shvaćanje važnosti cjeloživotnog učenja i povećanje uključenosti u lokalnu zajednicu. Zaključno, provedba projekata i ulaganje u ruralna područja predstavljaju investiciju u budućnost zbog raznolikosti procesa koje mogu aktivirati.
\end{abstract}

Ključne riječi: upravljanje resursima ruralnog područja, primarno istraživanje, prekogranična suradnja, regionalni razvoj, Europska unija. 